\title{
Effects of replacing wild rye, corn silage, or corn grain with CaO-treated corn stover and dried distillers grains with solubles in lactating cow diets on performance, digestibility, and profitability
}

\author{
H. T. Shi, ${ }^{*}$ S. L. Li, ${ }^{* 1}$ Z. J. Cao, ${ }^{* 1}$ Y. J. Wang, ${ }^{*}$ G. M. Alugongo, ${ }^{*}$ and P. H. Doane \\ *State Key Laboratory of Animal Nutrition, College of Animal Science and Technology, China Agricultural University, Beijing, 100193, P. R. China \\ †Archer Daniels Midland Research, Decatur, IL 62521
}

\begin{abstract}
The objective of this study was to measure the effects of partially replacing wild rye (Leymus chinensis; $\mathrm{WR}$ ), corn silage (CS), or corn grain (CG) in dairy cow diets with $\mathrm{CaO}$-treated corn stover (T-CS) and corn dried distillers grains with soluble (DDGS) on performance, digestibility, blood metabolites, and income over feed cost. Thirty tonnes of air-dried corn stover was collected, ground, and mixed with $5 \% \mathrm{CaO}$. Sixty-four Holstein dairy cows were blocked based on days in milk, milk yield, and parity and were randomly assigned to 1 of 4 treatments. The treatments were (1) a diet containing $50 \%$ concentrate, $15 \% \mathrm{WR}, 25 \% \mathrm{CS}$, and $10 \%$ alfalfa hay $(\mathrm{CON})$; (2) $15 \% \mathrm{WR}, 5 \% \mathrm{CG}$, and $6 \%$ soybean meal were replaced by $15 \%$ T-CS and $12 \%$ DDGS (RWR); (3) 12.5\% CS, $6 \%$ CG, and 5\% soybean meal were replaced by $12.5 \%$ T-CS and 12\%DDGS (RCS); (4) 13\% CG and 6\% soybean meal were replaced by 7\% T-CS and 13\% DDGS (RCG). Compared with CON treatment, cows fed RCS and RCG diets had similar dry matter intake (CON: $18.2 \pm 0.31 \mathrm{~kg}$, RCS: $18.6 \pm 0.31 \mathrm{~kg}$, and RCG: $18.4 \pm 0.40 \mathrm{~kg}$ ). The RWR treatment tended to have lower dry matter intake than other treatments. The inclusion of T-CS and DDGS in treatment diets as a substitute for WR, CS, or CG had no effects on lactose percentage (CON: $4.96 \pm 0.02 \%$, RWR: $4.97 \pm 0.02 \%$, RCS: $4.96 \pm 0.02 \%$, and RCG: $4.94 \pm 0.02 \%), 4 \%$ fat-corrected milk yield (CON: 22.7 $\pm 0.60 \mathrm{~kg}$, RWR: $22.1 \pm 0.60 \mathrm{~kg}$, RCS: $22.7 \pm 0.60 \mathrm{~kg}$, and RCG: $22.7 \pm 0.60 \mathrm{~kg})$, milk fat yield $(\mathrm{CON}: 0.90 \pm$ $0.03 \mathrm{~kg}$, RWR: $0.86 \pm 0.03 \mathrm{~kg}$, RCS: $0.87 \pm 0.03 \mathrm{~kg}$, and RCG: $0.89 \pm 0.03 \mathrm{~kg}$ ), and milk protein yield (CON: $0.74 \pm 0.02 \mathrm{~kg}$, RWR: $0.72 \pm 0.02 \mathrm{~kg}$, RCS: $0.73 \pm$ $0.02 \mathrm{~kg}$, and RCG: $0.71 \pm 0.02 \mathrm{~kg}$ ). Cows fed the RWR diet had higher apparent dry matter digestibility (73.7
\end{abstract}

Received December 22, 2014.

Accepted June 7, 2015.

${ }^{1}$ Corresponding authors: lisheng0677@163.com, caozhijun@cau.edu. \pm 1.30 vs. $70.2 \pm 1.15,69.9 \pm 1.15$, and $69.9 \pm 1.15 \%$ for RWR vs. CON, RCS, and RCG, respectively) and lower serum urea $\mathrm{N}(3.55 \pm 0.11$ vs. $4.03 \pm 0.11,3.95$ \pm 0.11 , and $3.99 \pm 0.11 \mathrm{mmol} / \mathrm{L}$ for RWR vs. CON, RCS, and RCG, respectively) than cows fed other diets. No significant differences were noted in apparent neutral detergent fiber digestibility among the treatments. Compared with CON treatment, the RWR, RCS, and RCG treatments generated an additional $\$ 0.77, \$ 0.70$, and $\$ 0.81$ income over feed cost per cow per day, respectively. In conclusion, feeding diets containing a portion of T-CS and DDGS can improve profitability of the treatment groups without negatively affecting the lactation performance of mid- to late-lactation cows. Key words: calcium oxide treatment, corn stover, income over feed cost, lactation performance

\section{INTRODUCTION}

Feed prices are regarded as the largest milk production expense (USDA-ERS, 2010). Traditionally, corn grain (CG), soybean meal, and high-quality forages have been the major feedstuffs used to support milk production in dairy cows in China (Cheng, 2013; Dong et al., 2013). In recent years, because of expanding demand, drought, and other adverse growing conditions, the price of CG, soybean meal, and some forages has risen to record high levels and has stayed at these levels for more than 2 yr in China. In 2014, in accordance with the survey data from Chinese Dairy Industry and Technology System, the average prices (DM basis) of CG, soybean meal, wild rye (Leymus chinensis; WR), and corn silage (CS) in China were about $\$ 444 / \mathrm{t}$, $\$ 718 / \mathrm{t}, \$ 210 / \mathrm{t}$, and $\$ 240 / \mathrm{t}$, respectively. The high feed costs have already been a main source of financial stress on Chinese dairy farmers (Cheng, 2013). To reduce feed costs farmers are looking at cheaper alternative feeds such as crop residues and ethanol coproducts.

Dried distillers grains with solubles (DDGS) are the major coproducts of the grain ethanol industry and are usually made from CG. Compared with CG, they are 
nutrient dense, containing an almost 3 -fold increase in protein, fat, and highly digestible fiber content (Schingoethe et al., 2009). Dried distillers grains with solubles are widely used in animal feeding as a source of protein and energy in dairy cows diets. China is rich in corn-stover resources, with an estimated production of 220 million tonnes (Lv et al., 2013). The use of corn stover by ruminants as roughage is limited by its poor digestibility, due to the high contents of lignin. Moreover, the lignin present in corn stover is interspersed with hemicelluloses, forming a matrix surrounding the orderly cellulose microfibrils, hence decreasing their digestibility (Wan and Li, 2010). Alkali treatment can improve the digestibility of poor-quality forage and crop residues, and the effectiveness of $\mathrm{NaOH}$ treatment in improving the digestibility of some crop residues has been demonstrated by several researchers (Jackson, 1977; Jami et al., 2014). Compared with $\mathrm{NaOH}, \mathrm{CaO}$ is less expensive and is safer to handle by unskilled workers, and the DM digestibility of CaO-treated crop residues is similar to that achieved with $\mathrm{NaOH}$ (Gandi et al., 1997). Some researchers have demonstrated the effectiveness of $\mathrm{CaO}$ treatment and anaerobic storage on the digestibility of corn stover (Shreck et al., 2011). The effects of feeding CaO-treated corn stover (T-CS) with distillers grains with solubles as a replacement for CG on the performance of beef cattle have also been evaluated (Shreck, 2013; Chapple, 2014). Results show that treating corn stover with $\mathrm{CaO}$ improved apparent total-tract fiber digestibility, and the T-CS, fed in combination with distillers grains with solubles, can replace up to 15 percentage units of corn without hindering performance of beef cattle. However, little data exists on the feeding of T-CS and DDGS to dairy cows.

Wild rye, CS, CG, and soybean meal have been widely used in the Chinese dairy industry, but their rising prices have reduced the Chinese dairy farmer's income over feed cost (IOFC). We hypothesize that partially replacing WR, CS, soybean meal, and CG with T-CS and DDGS would not significantly influence the performance of mid- to late-lactation dairy cows. Therefore, the objective of this experiment was to investigate effects of partially replacing WR, CS, and CG with T-CS and DDGS in a TMR on DMI, milk production, nutrient digestibility, blood metabolites, and profitability of mid- to late-lactating Holstein cows.

\section{MATERIALS AND METHODS}

\section{Treatments, Experimental Design, and Cow Management}

The feeding experiment was conducted at the Siyuan Dairy Farm (Pingdingshan City, Henan province,
China). About $30 \mathrm{t}$ of air-dried corn stover (variety, Zhengdan 958, DM $=87.7 \%$ ) was collected and ground through a 2.54-cm screen using a grinder (93QS-8.0; Zhengzhou Muchang Agricultural Machinery Manufacture Co. Ltd., Zhengzhou, China). It was then added to a TMR mixer (Labrador MT; Storti S. p. A., Verona, Italy) and wetted to $50 \%$ moisture. After wetting, $\mathrm{CaO}$ powder (Quick Lime; Yuanfeng Lime Co., Xinxiang, China) was added at $5 \%$ of dry weight of corn stover and allowed to mix in the wagon for $10 \mathrm{~min}$. Treated corn stover was unloaded and compacted into a bunker as tightly as possible. The bunker was sealed to ensure that the treated stover was kept under anaerobic conditions. The treatment process was completed $30 \mathrm{~d}$ before the start of the feeding experiment.

Two weeks before the start of the experiment, 8 primiparous and 56 multiparous Holstein dairy cows (DIM $=135 \pm 16 ;$ milk yield $=26.7 \pm 2.8 \mathrm{~kg} ;$ parities $=2.8$ $\pm 1.1 ; \mathrm{BW}=607 \pm 28 \mathrm{~kg}$ ) were blocked into 16 groups based on DIM, milk yield, and parity (cows within each block had the same parity) and were randomly allocated to 1 of 4 treatments.

The dietary treatments were (1) a diet containing $50 \%$ concentrate, $15 \% \mathrm{WR}, 25 \% \mathrm{CS}$, and $10 \%$ alfalfa hay (CON); (2) 15\% WR, 5\% CG, and 6\% soybean meal were replaced by $15 \%$ T-CS and $12 \%$ DDGS (RWR); (3) $12.5 \%$ CS, 6\% CG, and 5\% soybean meal were replaced by $12.5 \%$ T-CS and $12 \%$ DDGS (RCS); and (4) $13 \%$ CG and $6 \%$ soybean meal were replaced by $7 \%$ T-CS and 13\% DDGS (RCG). Diets were formulated to be isonitrogenous and isocaloric and met NRC (2001) requirements. Ingredients and nutrient levels of the diets are presented in Table 1 . The 4 groups were fed the 4 diets for $14 \mathrm{~d}$ of adaptation to the diets, followed by $12 \mathrm{wk}$ of the experimental period. Cows were housed individually in free stalls and offered the TMR thrice daily at 0600,1300 , and $1900 \mathrm{~h}$, permitting 5 to $10 \%$ orts with unlimited access to fresh water. Animal care for this experiment complied with the practices outlined in the Guide for the Care and Use of Agricultural Animals in Research and Teaching (FASS, 2010).

\section{Data and Sample Collection}

Milk Yield and Milk Components. All cows on the farm were milked 3 times daily at 0430, 1230, and $2030 \mathrm{~h}$ in a milking parlor. Daily milk yield of the experimental cows was collected. Every $14 \mathrm{~d}$, a 50-mL aliquot of the milk sample was collected at each milking of the sampling day, proportional to the yield (equal proportions, composite). Milk samples were preserved with potassium dichromate and kept at $4^{\circ} \mathrm{C}$ until analyzed for protein, fat, lactose, MUN, and TS by an automated near-infrared milk analyzer (CombiFoss 
Table 1. Ingredients and chemical composition of the diets

\begin{tabular}{|c|c|c|c|c|}
\hline \multirow[b]{2}{*}{ Item } & \multicolumn{4}{|c|}{ Treatment $^{1}$} \\
\hline & $\mathrm{CON}$ & RWR & RCS & RCG \\
\hline \multicolumn{5}{|l|}{ Ingredient, $\%$} \\
\hline Corn grain & 31.0 & 26.0 & 25.0 & 18.0 \\
\hline Soybean meal & 9.0 & 3.0 & 4.0 & 3.0 \\
\hline DDGS & - & 12.0 & 12.0 & 13.0 \\
\hline Treated stover & - & 15.0 & 12.5 & 7.0 \\
\hline Wild rye & 15.0 & - & 15.0 & 15.0 \\
\hline Corn silage & 25.0 & 25.0 & 12.5 & 25.0 \\
\hline Cottonseed meal & 7.0 & 7.0 & 7.0 & 7.0 \\
\hline Alfalfa hay & 10.0 & 10.0 & 10.0 & 10.0 \\
\hline $\mathrm{NaCl}$ & 0.5 & 0.5 & 0.5 & 0.5 \\
\hline $\mathrm{NaHCO}_{3}$ & 0.5 & 0.5 & 0.5 & 0.5 \\
\hline $\mathrm{CaHPO}_{4}$ & 0.5 & 0.5 & 0.5 & 0.1 \\
\hline Limestone & 1.0 & - & - & 0.4 \\
\hline Mineral-vitamin premix ${ }^{2}$ & 0.5 & 0.5 & 0.5 & 0.5 \\
\hline \multicolumn{5}{|l|}{ Chemical composition } \\
\hline $\mathrm{CP}, \%$ of $\mathrm{DM}$ & 15.6 & 15.6 & 15.7 & 15.6 \\
\hline $\mathrm{NE}_{\mathrm{L}}, \mathrm{Mcal} / \mathrm{kg}$ of $\mathrm{DM}$ & 1.53 & 1.54 & 1.52 & 1.49 \\
\hline $\mathrm{NDF}, \%$ of DM & 34.5 & 35.2 & 38.9 & 40.7 \\
\hline $\mathrm{FNDF},{ }^{3} \%$ of DM & 28.9 & 27.4 & 31.2 & 33.5 \\
\hline $\mathrm{ADF}, \%$ of $\mathrm{DM}$ & 20.3 & 20.9 & 22.8 & 23.6 \\
\hline Ether extract, $\%$ of DM & 2.64 & 3.41 & 3.33 & 3.44 \\
\hline $\mathrm{OM}, \%$ of DM & 92.7 & 91.2 & 91.5 & 92.2 \\
\hline Starch, \% of DM & 28.7 & 25.5 & 22.2 & 20.4 \\
\hline $\mathrm{NFC},{ }^{4} \%$ of DM & 40.1 & 37.1 & 33.5 & 32.5 \\
\hline $\mathrm{Ca}, \%$ of $\mathrm{DM}$ & 0.86 & 1.00 & 0.91 & 0.81 \\
\hline $\mathrm{P}, \%$ of $\mathrm{DM}$ & 0.42 & 0.47 & 0.47 & 0.41 \\
\hline
\end{tabular}

${ }^{1} \mathrm{CON}=$ control RWR $=15 \%$ wild rye, $5 \%$ corn grain $(\mathrm{CG})$, and $6 \%$ soybean meal were replaced by $15 \%$ CaO-treated corn stover (T-CS) and $12 \%$ dried distillers grains with solubles (DDGS); RCS $=12.5 \%$ corn silage, $6 \% \mathrm{CG}$, and $5 \%$ soybean meal were replaced by $12.5 \%$ T-CS and $12 \%$ DDGS; RCG $=13 \% \mathrm{CG}$ and $6 \%$ soybean meal were replaced by $7 \%$ T-CS and $13 \%$ DDGS.

${ }^{2}$ Contained $95 \mathrm{mg}$ of $\mathrm{I} / \mathrm{kg}, 2,800 \mathrm{mg}$ of $\mathrm{Fe} / \mathrm{kg}, 1,750 \mathrm{mg}$ of $\mathrm{Cu} / \mathrm{kg}$, $2,550 \mathrm{mg}$ of $\mathrm{Mn} / \mathrm{kg}, 5,500 \mathrm{mg}$ of $\mathrm{Zn} / \mathrm{kg}, 50 \mathrm{mg}$ of $\mathrm{Co} / \mathrm{kg}, 800,000 \mathrm{IU}$ of vitamin $\mathrm{A} / \mathrm{kg}, 65,000 \mathrm{IU}$ of vitamin $\mathrm{D} / \mathrm{kg}, 5,100 \mathrm{IU}$ of vitamin $\mathrm{E} /$ $\mathrm{kg}$, and $75 \mathrm{mg}$ of $\mathrm{Se} / \mathrm{kg}$.

${ }^{3} \mathrm{FNDF}=$ forage NDF.

${ }^{4} \mathrm{NFC}=\mathrm{OM}-(\mathrm{CP}+\mathrm{NDF}+$ fat $)$.

FT+; Foss Electric, Hillerød, Denmark) in Henan DHI Testing Center (Zhengzhou, China).

DMI and In Vivo Digestibility. The amount of TMR offered was recorded every day, the orts of individual cow were collected and weighed, and the DMI was calculated based on the feed offered and orts. The feedstuffs were sampled weekly to determine the DM content. Daily TMR and orts samples were pooled by treatment, and then the subsample was oven dried at $65^{\circ} \mathrm{C}$ for $48 \mathrm{~h}$, ground through a 1-mm screen using a Wiley mill (standard model 4, Arthur H. Thomas Co., Philadelphia, PA), and stored at $-20^{\circ} \mathrm{C}$ for the analysis of DM, OM, CP, NDF, and ADF. During the last week of the experiment, 4 cows from each treatment with similar DMI and milk yield $(\mathrm{DMI}=18.51 \pm 0.82$; milk yield $=24.5 \pm 0.48$ ) were selected for a 4 -d digestibility test. The floor was cushioned with rubber mats dur- ing this procedure. Sixteen fecal-collection containers were prepared and were responsible for collecting fecal samples of individual cows. After every $24 \mathrm{~h}$, the total fecal matter collected was weighed, mixed, and recorded. About $2 \%$ of the mixed feces was sampled, oven dried (YSL-DJG-9140A; Beijing Yashilin Test Equipment Co. Ltd., Beijing, China) at $65^{\circ} \mathrm{C}$ for $48 \mathrm{~h}$, ground through a 1-mm screen (Wiley mill), and stored at $-20^{\circ} \mathrm{C}$ for later analysis of $\mathrm{DM}, \mathrm{OM}, \mathrm{CP}, \mathrm{NDF}$, and ADF.

Blood Collection and Serum Preparation. Serum samples were collected every 2 wk during this experiment. Blood was collected from the coccygeal vein into $10-\mathrm{mL}$ evacuated serum tubes (Vacutainer; Becton Dickinson, Franklin Lakes, NJ). All the tubes were centrifuged at $3,000 \times g$ at $4^{\circ} \mathrm{C}$ for $15 \mathrm{~min}$ to obtain serum, which was separated into 4 aliquots and stored at $-20^{\circ} \mathrm{C}$ until further analysis.

$B C S$ and IOFC. All cows were scored for body condition from 1 (thin) to 5 (fat) (Edmonson et al., 1989) on d 30,60, and 90 by 3 trained observers. The average prices (DM basis; February 2013) of CS (\$245/t) and T-CS $(\$ 126.82 / \mathrm{t})$ were determined by the actual production costs of the farm. The average prices (DM basis; February to June 2013) of CG (\$423/t), DDGS $(\$ 440 / \mathrm{t})$, soybean meal $(\$ 716 / \mathrm{t})$, WR $(\$ 229 / \mathrm{t})$, and other ingredients were determined by the purchased price of the farm. Milk price was also monitored during the experiment, and daily per cow IOFC of each treatment was calculated every $14 \mathrm{~d}$ by subtracting feed costs from milk production income.

\section{Analytical Procedures}

In Situ Disappearance. In situ effective disappearance of WR, CS, untreated stover, and T-CS was measured by the procedure proposed by Ørskov et al. (1980). Four nonlactating Holstein cows equipped with a rumen fistula were placed in individual pens at the experimental dairy farm of China Agricultural University (Beijing) and fed a diet formulated according to the NRC (2001) requirements (contained 15\% T-CS, $15 \%$ WR, 20\% CS, $10 \%$ alfalfa hay, and $40 \%$ concentrate mixture on a DM basis). The forage samples were ground through a 3 -mm screen in a Wiley mill (Arthur H. Thomas Co.). Three grams of each sample was weighted into nylon bags $(10 \mathrm{~cm} \times 20 \mathrm{~cm}, 50-\mu \mathrm{m}$ pore size) and then placed in the ventral sac of the rumen after the morning feeding and removed after 2, 4, 8, 12, $24,36,48$, and $72 \mathrm{~h}$. After removal from the rumen, the bags were rinsed in cold running tap water until the wash water ran clear. The washed bags were then dried in the forced-air oven (model 2000; Experimental Mil, 
Beijing, China) at $65^{\circ} \mathrm{C}$ for $48 \mathrm{~h}$. In situ residues and original feed samples were analyzed for DM and NDF.

Chemical Composition. The DM of feed and feces samples was determined at $65^{\circ} \mathrm{C}$ for $48 \mathrm{~h}$ by a forced-air oven (model 2000; Experimental Mil). Ash content was determined by incineration at $550^{\circ} \mathrm{C}$ for $4 \mathrm{~h}$ in a muffle furnace (AOAC, 1990; method 934.01), and the OM content was calculated as the difference between 100 and the percentage of ash. Crude protein was analyzed using the Kjeldahl procedure (AOAC, 1990; method 990.03). The content of NDF, ADF, ADL, and residual ash was measured using the sequential method of Van Soest et al. (1991). An ANKOM ${ }^{2000}$ fiber analyzer (Ankom Technology Corp., Macedon, NY) was used to extract and filter NDF and $\mathrm{ADF}$, and $\alpha$-amylase and sodium sulfite were used for the NDF procedure. Crude fat was determined using an $\mathrm{ANKOM}^{\mathrm{XT15}}$ Extractor (Ankom Technology Corp.). Calcium (AOAC, 1990; method 927.02) and total phosphorus (AOAC, 1990; method 965.05) was determined using the dry-ashed residue method. All analyses were conducted in triplicate. Content of lignin was calculated as ADL - residual ash, cellulose as ADF - ADL, and hemicellulose as NDF - ADF.

Blood Analysis. The levels of glucose, BUN, total cholesterol (TC), triglycerides, BHBA, and NEFA in serum were analyzed using a clinical autoanalyzer (Hitachi 7020; Hitachi, Tokyo, Japan). Commercially available kits (Nanjing Jiancheng Biology Research Institute, Nanjing, China) were used for the blood analysis. The glucose and BUN concentrations were determined using the glucose oxidase-peroxidase antiperoxidase and glutamate dehydrogenase test kits. The TC, triglycerides, BHBA, and NEFA concentrations were determined following the kit instructions, using the enzymatic methods.

Statistical Analysis. Data were analyzed using the PROC MIXED procedure of SAS (SAS Institute Inc., Cary, NC). A randomized complete block design with repeated measures was used, with time, diet, and interaction of diet by time as fixed effects. Preliminary variables for DMI, lactation performance, BCS, and serum metabolites were used as covariates in each of respective models but were found to have no effect on the outcome, so they were dropped from the model. The model used to analyze the data was

$$
Y_{i j k}=\mu+\operatorname{cow}_{i}+\operatorname{trt}_{j}+\text { time }_{k}+\operatorname{trt}_{j} \times \text { time }_{k}+E_{i j k},
$$

where $Y_{i j k}$ is the dependent variable, $\mu$ is the overall mean, $\operatorname{cow}_{i}$ is the random effect of block $i, \operatorname{trt}_{j}$ is the fixed effect of the $j$ th treatment, time $_{k}$ is the effect of the $k$ th sample collection time, $\operatorname{trt}_{j} \times$ time $_{k}$ is the fixed effect of the interaction between the $j$ th treatment and the $k$ th time, and $E_{i j k}$ is the residual error. For the repeated measures analysis, the covariance structure with the least Akaike information criterion was used. The time effect and interactions of the time with treatment were not significant for the data on nutrient digestibility, blood analysis, and IOFC; therefore, these are not further reported. Results were reported as least squares means, and the PDIFF option was used to test for treatment differences among least squares means. Significant differences were declared at $P \leq 0.05$, and trends were reported at $0.05<P \leq 0.10$.

\section{RESULTS}

\section{Chemical Composition and In Situ Degradability of Forages}

Data in Table 2 show that $\mathrm{CaO}$ treatment decreased the OM content of corn stover and resulted in decreased amounts of other constituents. When treated by $5 \% \mathrm{CaO}$, the NDF content (OM basis) of corn stover decreased from 82.7 to $72.1 \%$. However, the untreated stover and T-CS had similar cellulose and lignin content when compared on an OM basis. The in situ effective degradability of DM and NDF of T-CS was similar to that of CS.

\section{Feed Intake, Milk Production, and BCS}

The results of DMI, lactation performance, and BCS are listed in Table 3. No significant difference was observed in $4 \% \mathrm{FCM}$ yield $(P=0.69), 4 \% \mathrm{FCM}$ production efficiency $(P=0.31)$, milk lactose content $(P=$ $0.89)$, milk fat yield $(P=0.45)$, milk protein yield $(P=$ $0.27)$, and BCS $(P=0.92)$ among the treatments. The RCS treatment had lower $(P<0.01)$ milk fat content than the CON and RCG treatments $(3.57 \pm 0.09$ vs. $3.93 \pm 0.09$ and $3.80 \pm 0.09 \%)$. The CON treatment had higher $(P<0.01)$ milk protein content $(3.22 \pm$ $0.02 \%)$, TS content $(12.59 \pm 0.07 \%)$, and MUN concentration $(14.2 \pm 0.28 \mathrm{mg} / \mathrm{dL})$ than other treatments, but no difference $(P=0.27)$ in milk protein yield was observed among the treatments. The DMI tended to $(P$ $=0.09)$ decrease for the RWR treatment $(17.6 \pm 0.31$ $\mathrm{kg} / \mathrm{d})$ compared with other treatments $(18.2 \pm 0.31$, $18.6 \pm 0.31$, and $18.4 \pm 0.40 \mathrm{~kg} / \mathrm{d}$ for the CON, RCS, and RCG treatment, respectively). The average milk yield tended to $(P=0.08)$ increase for the RCS treatment from d 28 to the end of the experiment (Figure 1) compared with other treatments. The DMI $(P=0.04)$, milk yield $(P=0.02)$, milk protein content $(P<0.01)$, MUN $(P<0.01)$, and BCS $(P<0.01)$ were affected by time. The interaction of treatment by time was not 
Table 2. Chemical composition ( $\mathrm{g} / \mathrm{kg}$ of $\mathrm{DM} ; \pm \mathrm{SE}$ ) and in situ effective degradability (\%) of wild rye (WR), corn silage (CS), untreated corn stover, and $5 \%$ CaO-treated corn stover (T-CS)

\begin{tabular}{lrrrr}
\hline Item & \multicolumn{1}{c}{ WR } & \multicolumn{1}{c}{ CS } & Untreated stover & T-CS $^{1}$ \\
\hline $\mathrm{DM}, \mathrm{g} / \mathrm{kg}$ & $878 \pm 11.2$ & $273 \pm 14.5$ & $874 \pm 10.1$ & $529 \pm 12.5$ \\
$\mathrm{OM}$ & $948 \pm 13.4$ & $952 \pm 11.3$ & $921 \pm 10.2$ & $852 \pm 11.9$ \\
$\mathrm{CP}$ & $73.2 \pm 1.68$ & $86.6 \pm 1.33$ & $63.2 \pm 1.24$ & $59.6 \pm 1.40$ \\
Ether extract & $12.7 \pm 0.42$ & $28.1 \pm 0.40$ & $8.40 \pm 0.21$ & $8.25 \pm 0.32$ \\
NDF & $732 \pm 7.12$ & $465 \pm 4.08$ & $762 \pm 8.05$ & $614 \pm 9.11$ \\
Hemicellulose & $285 \pm 7.60$ & $197 \pm 5.37$ & $281 \pm 5.64$ & $195 \pm 7.29$ \\
Cellulose & $364 \pm 6.62$ & $217 \pm 7.70$ & $403 \pm 3.44$ & $369 \pm 7.13$ \\
Lignin & $62.1 \pm 1.01$ & $40.2 \pm 2.69$ & $59.1 \pm 2.09$ & $51.2 \pm 2.17$ \\
Ca & $4.15 \pm 0.09$ & $4.77 \pm 0.12$ & $5.49 \pm 0.21$ & $31.3 \pm 1.23$ \\
P & $2.70 \pm 0.04$ & $2.67 \pm 0.09$ & $0.87 \pm 0.01$ & $0.86 \pm 0.01$ \\
ISDMD ${ }^{2} \%$ of DM & $40.6 \pm 1.35$ & $47.3 \pm 1.27$ & $36.2 \pm 1.36$ & $46.1 \pm 1.20$ \\
ISNDFD, ${ }^{2} \%$ of NDF & $37.5 \pm 2.06$ & $44.5 \pm 1.79$ & $34.2 \pm 2.44$ & $45.1 \pm 1.90$ \\
\hline
\end{tabular}

${ }^{1}$ The $\mathrm{CaO}$ treatment was conducted by mixing ground corn stover (wetted to $50 \%$ moisture) with $\mathrm{CaO}$ (5\% of dry-stover basis) in the wagon. The treated stover was compacted into a bunker for $30 \mathrm{~d}$.

${ }^{2} \mathrm{ISDMD}=$ in situ effective DM degradability; ISNDFD = in situ effective NDF degradability.

significant except the MUN. The MUN concentration was lower $(P<0.01)$ for the RWR treatment during wk 6 to 12 relative to other treatments.

\section{Nutrient Digestibility}

The results of nutrient digestibility are listed in Table 4. The apparent digestibility of DM was higher $(P<$ $0.01)$ for cows fed the RWR treatment $(73.7 \pm 1.30 \%)$ compared with other treatments $(70.2 \pm 1.15,69.9 \pm$
1.15 , and $69.9 \pm 1.15 \%$ for the CON, RCS, and RCG treatment, respectively). Cows in RWR treatment also had a higher $(P<0.01)$ OM digestibility $(74.7$ $\pm 1.21 \%$ ) than cows in the RCS and RCG treatments $(70.6 \pm 1.20$ and $70.3 \pm 1.20 \%)$, and a higher $(P=$ $0.04)$ apparent ADF digestibility $(59.9 \pm 1.08 \%)$ than cows fed the CON and RCG diets $(50.9 \pm 1.08$ and 52.8 $\pm 1.08 \%)$. Relative to the RCG treatment, the apparent digestibility of $\mathrm{CP}$ tended to $(P=0.09)$ increase for the RWR treatment.

Table 3. The DMI, BCS, milk yield, and composition as influenced by diets

\begin{tabular}{|c|c|c|c|c|c|c|c|c|}
\hline Item & \multicolumn{4}{|c|}{ Treatment $^{1}$} & SEM & \multicolumn{3}{|c|}{$P$-value ${ }^{2}$} \\
\hline DMI, $\mathrm{kg} / \mathrm{d}$ & 18.2 & 17.6 & 18.6 & 18.4 & 0.46 & 0.09 & 0.04 & 0.94 \\
\hline Milk & 23.2 & 23.2 & 24.6 & 23.6 & 1.29 & 0.08 & 0.02 & 0.81 \\
\hline $4 \% \mathrm{FCM}^{3}$ & 22.7 & 22.1 & 22.7 & 22.7 & 0.82 & 0.69 & 0.15 & 0.71 \\
\hline \multicolumn{9}{|l|}{ Component, \% } \\
\hline TS & $12.59^{\mathrm{a}}$ & $12.28^{\mathrm{b}}$ & $12.07^{\mathrm{b}}$ & $12.30^{\mathrm{b}}$ & 0.08 & $<0.01$ & 0.13 & 0.62 \\
\hline \multicolumn{9}{|l|}{ Yield, $\mathrm{kg} / \mathrm{d}$} \\
\hline Fat & 0.90 & 0.86 & 0.87 & 0.89 & 0.10 & 0.45 & 0.42 & 0.70 \\
\hline Protein & 0.74 & 0.72 & 0.73 & 0.71 & 0.09 & 0.27 & 0.11 & 0.59 \\
\hline Lactose yield & 1.14 & 1.15 & 1.20 & 1.15 & 0.12 & 0.11 & 0.06 & 0.74 \\
\hline MUN, mg/dL & $14.2^{\mathrm{a}}$ & $12.4^{\mathrm{c}}$ & $13.3^{\mathrm{b}}$ & $13.5^{\mathrm{b}}$ & 0.45 & $<0.01$ & $<0.01$ & $<0.01$ \\
\hline
\end{tabular}

${ }^{\mathrm{a}-\mathrm{c}}$ Least squares means within the same row without a common superscript differ $(P<0.05)$.

${ }^{1} \mathrm{CON}=$ control; RWR $=15 \%$ wild rye, $5 \%$ corn grain $(\mathrm{CG})$, and $6 \%$ soybean meal were replaced by $15 \%$ CaO-treated corn stover $(\mathrm{T}$-CS) and $12 \%$ dried distillers grains with solubles (DDGS); RCS $=12.5 \%$ corn silage, $6 \% \mathrm{CG}$, and $5 \%$ soybean meal were replaced by $12.5 \%$ T-CS and $12 \%$ DDGS; RCG $=13 \%$ CG and $6 \%$ soybean meal were replaced by $7 \%$ T-CS and $13 \%$ DDGS.

${ }^{2} \mathrm{~T}=$ treatment effect; $\mathrm{P}=$ time effect; $\mathrm{T} \times \mathrm{P}=$ the interaction between treatment and time.

${ }^{3} 4 \% \mathrm{FCM}=0.4 \times$ milk yield $(\mathrm{kg} / \mathrm{d})+15 \times$ fat yield $(\mathrm{kg} / \mathrm{d})($ Tyrrell and Reid, 1965$)$. 
Table 4. In vivo apparent digestibility of dietary components as influenced by diets

\begin{tabular}{lllllrr}
\hline & \multicolumn{9}{c}{ Treatment $^{1}$} & & \\
\cline { 2 - 4 } Item, \% & CON & RWR & RCS & RCG & SEM & $P$-value \\
\hline DM & $70.2^{\mathrm{b}}$ & $73.7^{\mathrm{a}}$ & $69.9^{\mathrm{b}}$ & $69.9^{\mathrm{b}}$ & 1.56 & $<0.01$ \\
OM & $72.6^{\mathrm{ab}}$ & $74.7^{\mathrm{a}}$ & $70.6^{\mathrm{b}}$ & $70.3^{\mathrm{b}}$ & 1.52 & $<0.01$ \\
CP & 72.3 & 75.4 & 71.2 & 70.6 & 1.64 & 0.09 \\
NDF & 59.2 & 64.2 & 60.5 & 61.1 & 2.23 & 0.37 \\
ADF & $50.9^{\mathrm{b}}$ & $59.9^{\mathrm{a}}$ & $53.9^{\mathrm{ab}}$ & $52.8^{\mathrm{b}}$ & 2.25 & 0.04 \\
\hline
\end{tabular}

$\overline{\mathrm{a}, \mathrm{b}}$ Least squares means within the same row without a common superscript differ $(P<0.05)$.

${ }^{1} \mathrm{CON}=$ control; RWR $=15 \%$ wild rye, $5 \%$ corn grain $(\mathrm{CG})$, and $6 \%$ soybean meal were replaced by $15 \% \mathrm{CaO}-$ treated corn stover (T-CS) and 12\% dried distillers grains with solubles (DDGS); RCS $=12.5 \%$ corn silage, $6 \%$ CG, and $5 \%$ soybean meal were replaced by $12.5 \%$ T-CS and $12 \%$ DDGS; RCG $=13 \%$ CG and $6 \%$ soybean meal were replaced by $7 \%$ T-CS and $13 \%$ DDGS.

\section{Blood Analysis}

Effects of different diets on serum metabolites are presented in Table 5. The CON and RWR treatments had lower $(P<0.01)$ serum TC concentrations $(4.77 \pm$ 0.10 and $4.74 \pm 0.10 \mathrm{mmol} / \mathrm{L})$ than the RCS and RCG treatments $(5.29 \pm 0.10$ and $5.67 \pm 0.11 \mathrm{mmol} / \mathrm{L})$. The RWR treatments had lower $(P<0.01)$ BUN concentrations $(3.55 \pm 0.11 \mathrm{mmol} / \mathrm{L})$ than other treatments $(4.03 \pm 0.11,3.95 \pm 0.11$, and $3.99 \pm 0.11 \mathrm{mmol} / \mathrm{L}$ for the CON, RCS, and RCG treatments, respectively). No significant differences were observed in serum triglycerides, glucose, BHBA, and NEFA concentrations among the treatments.

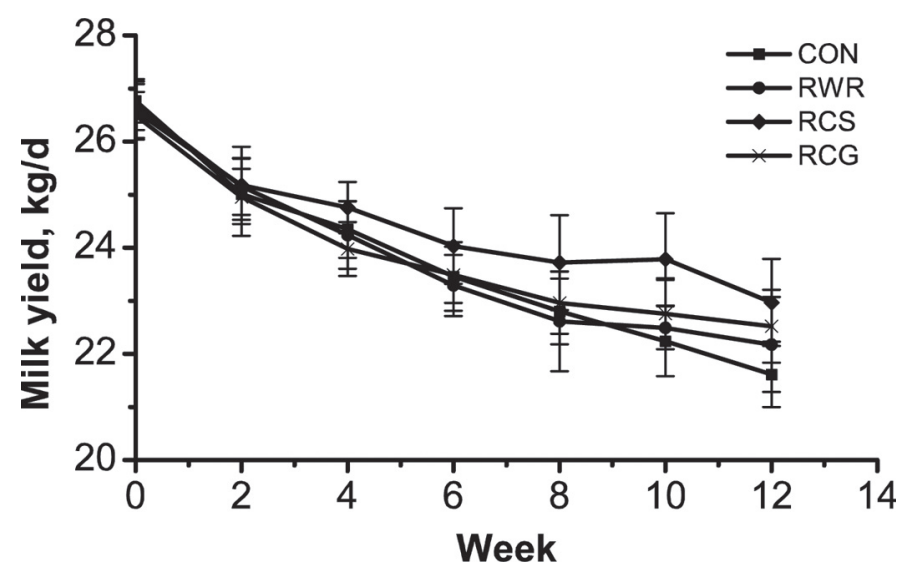

Figure 1. Change in milk yield of lactating cows fed different diets. Treatments: $\mathrm{CON}=$ control; RWR $=15 \%$ wild rye, $5 \%$ corn grain (CG), and $6 \%$ soybean meal were replaced by $15 \%$ CaO-treated corn stover (T-CS) and $12 \%$ dried distillers grains with solubles (DDGS); $\mathrm{RCS}=12.5 \%$ corn silage, $6 \% \mathrm{CG}$, and $5 \%$ soybean meal were replaced by $12.5 \%$ T-CS and 12\% DDGS; RCG $=13 \% \mathrm{CG}$ and $6 \%$ soybean meal were replaced by $7 \%$ T-CS and $13 \%$ DDGS. The milk yield tended to increase for the RCS treatment from d 28 to the end of the experiment $(P=0.08)$ compared with other treatments. Bars indicate the standard error.

\section{Economic Benefits}

The IOFC (\$/cow per day) for the treatments is presented in Table 6. Feeding diets containing T-CS and DDGS to cows could reduce feed costs effectively. Milk income was not affected by the treatments $(P=$ $0.51)$, whereas the feed costs for cows fed the RWR, RCS, and RCG diets were lower $(P<0.01)$ than for those fed the CON diet $(7.65 \pm 0.04,8.19 \pm 0.04$, and $7.78 \pm 0.04$ vs. $8.49 \pm 0.05 \$ /$ cow per day). Calculated IOFC ( $\$ /$ cow per day) for the CON, RWR, RCS, and RCG treatments were $\$ 7.35 \pm 0.06, \$ 8.12 \pm 0.06, \$ 8.05$ \pm 0.06 , and $\$ 8.16 \pm 0.06$, respectively. Relative to the CON treatment, the RWR, RCS, and RCG treatments generated an additional $\$ 0.77, \$ 0.70$, and $\$ 0.81$ IOFC per cow per day, respectively.

\section{DISCUSSION}

\section{Forage Composition and DMI}

The ash and Ca content of corn stover was increased by $\mathrm{CaO}$ treatment. Similar findings were reported by Zaman and Owen (1995) when straw was treated by $\mathrm{Ca}(\mathrm{OH})_{2}$, because calcium remains in the substrate after the chemical reaction. Decreased NDF content and increased in situ effective disappearance of T-CS were noted in the present study. These findings were consistent with previous studies, which reported that alkali treatment could partially solubilize the hemicelluloses and labile phenolic fractions in fibers, increasing the digestibility of crop residues (Miron and Ben-Ghedalia, 1987a,b; Sirohi and Rai, 1998). The slight decrease in $\mathrm{CP}$ of T-CS might be partly due to the relative increase in ash content. Bal et al. (1997) reported that the proper DM content for CS was between 32 and $35 \%$. The DM of CS used in this experiment was $27.3 \%$. However, it represented the actual quality level of the widely used CS on Chinese dairy farms currently (Cao et al., 2015). As a major forage source for lactating 
Table 5. Effects of different diets on serum metabolites of cows

\begin{tabular}{|c|c|c|c|c|c|c|}
\hline \multirow[b]{2}{*}{ Item } & \multicolumn{4}{|c|}{ Treatment $^{1}$} & \multirow[b]{2}{*}{ SEM } & \multirow[b]{2}{*}{$P$-value } \\
\hline & $\mathrm{CON}$ & RWR & $\mathrm{RCS}$ & $\mathrm{RCG}$ & & \\
\hline Total cholesterol, $\mathrm{mmol} / \mathrm{L}$ & $4.77^{\mathrm{b}}$ & $4.74^{\mathrm{b}}$ & $5.29^{\mathrm{a}}$ & $5.67^{\mathrm{a}}$ & 0.18 & $<0.01$ \\
\hline Triglycerides, mmol/L & 0.15 & 0.15 & 0.15 & 0.16 & $<0.01$ & 0.36 \\
\hline $\mathrm{BUN}, \mathrm{mmol} / \mathrm{L}$ & $4.03^{\mathrm{a}}$ & $3.55^{\mathrm{b}}$ & $3.95^{\mathrm{a}}$ & $3.99^{\mathrm{a}}$ & 0.12 & 0.02 \\
\hline Glucose, $\mathrm{mmol} / \mathrm{L}$ & 2.86 & 2.72 & 2.76 & 2.81 & 0.08 & 0.66 \\
\hline BHBA, mmol/L & 0.60 & 0.53 & 0.54 & 0.56 & 0.03 & 0.34 \\
\hline $\mathrm{NEFA}, \mu \mathrm{Eq} / \mathrm{L}$ & 124.41 & 122.76 & 114.98 & 125.18 & 4.41 & 0.84 \\
\hline
\end{tabular}

dairy cows, although the quality of CS on Chinese dairy farms has been improving in recent years, it is still less than ideal, mainly because of the improper harvest stage (immature), which could limit the DM yield and feeding value of CS (Bal et al., 1997; Cao et al., 2015). Wild rye is also a common forage in China, but because of its rising price and relatively low feeding value, dairy farmers have taken interest in replacing it with other lower-cost feedstuffs. In the present study, the T-CS had better in situ effective NDF degradability than WR $(45.1 \pm 1.90 \%$ vs. $37.5 \pm 2.06 \%)$, thus motivating the use of T-CS and DDGS as WR replacer in TMR fed to lactating cows.

Dry matter intake is generally recognized as one of the most important factors influencing dairy cow performance (Arelovich et al., 2008). Feed intake can be regulated by both physiological factors and external factors, and the common external factors may include chemical composition of the diet, environmental conditions (NRC, 2001), and animal learning abilities (Forbes and Provenza, 2000). Among the various chemical components, NDF has been proposed as a reliable predictor of voluntary intake when low-energy, high-fiber rations are fed to animals (Van Soest, 1994). The relationship between dietary NDF and voluntary intakes of DM has been evaluated by Arelovich et al. (2008). For dietary NDF content ranging from 22.5 to $45.8 \%$, DMI (\% of $\mathrm{BW}$ and $\mathrm{kg}$ of DM/d per animal) decreased (coefficient of determination $=0.595$ and 0.672 , respectively) with increasing NDF content.

In the present study, the RWR, RCS, and RCG diets had higher NDF content than the CON diet. However,

Table 6. Effects of different treatments on income over feed cost

\begin{tabular}{|c|c|c|c|c|c|c|}
\hline \multirow[b]{2}{*}{ Item } & \multicolumn{4}{|c|}{ Treatment $^{1}$} & \multirow[b]{2}{*}{ SEM } & \multirow[b]{2}{*}{$P$-value } \\
\hline & $\mathrm{CON}$ & RWR & RCS & RCG & & \\
\hline \multicolumn{7}{|l|}{ Feed cost, $\$ /$ cow per day } \\
\hline Corn grain & $2.35^{\mathrm{a}}$ & $1.89^{\mathrm{b}}$ & $1.93^{\mathrm{b}}$ & $1.39^{\mathrm{c}}$ & 0.04 & $<0.01$ \\
\hline Soybean meal & $1.15^{\mathrm{a}}$ & $0.37^{\mathrm{c}}$ & $0.52^{\mathrm{b}}$ & $0.39^{\mathrm{c}}$ & 0.07 & $<0.01$ \\
\hline DDGS & - & $0.91^{\mathrm{b}}$ & $0.96^{\mathrm{b}}$ & $1.05^{\mathrm{a}}$ & 0.05 & $<0.01$ \\
\hline Cottonseed meal & 0.65 & 0.63 & 0.67 & 0.67 & 0.01 & 0.06 \\
\hline Corn silage & $1.10^{\mathrm{a}}$ & $1.06^{\mathrm{b}}$ & $0.56^{\mathrm{c}}$ & $1.12^{\mathrm{a}}$ & 0.13 & $<0.01$ \\
\hline Alfalfa hay & $0.84^{\mathrm{a}}$ & $0.81^{\mathrm{b}}$ & $0.86^{\mathrm{a}}$ & $0.86^{\mathrm{a}}$ & 0.01 & 0.04 \\
\hline Wild rye & 0.67 & - & 0.68 & 0.68 & 0.06 & $<0.01$ \\
\hline Treated stover & - & $0.33^{\mathrm{a}}$ & $0.29^{\mathrm{b}}$ & $0.16^{\mathrm{c}}$ & 0.06 & $<0.01$ \\
\hline Mineral and vitamin ${ }^{2}$ & $1.72^{\mathrm{a}}$ & $1.65^{\mathrm{b}}$ & $1.69^{\mathrm{a}}$ & $1.45^{\mathrm{c}}$ & 0.03 & $<0.01$ \\
\hline Total feed cost, $\$ /$ cow per day & $8.49^{\mathrm{a}}$ & $7.65^{\mathrm{c}}$ & $8.19^{\mathrm{b}}$ & $7.78^{\mathrm{c}}$ & 0.05 & $<0.01$ \\
\hline Milk price, $\$ / \mathrm{kg}$ & $0.69^{\mathrm{a}}$ & $0.68^{\mathrm{b}}$ & $0.67^{\mathrm{c}}$ & $0.68^{\mathrm{b}}$ & 0.01 & $<0.01$ \\
\hline Milk income, \$/cow per day & 15.83 & 15.76 & 16.24 & 15.94 & 0.12 & 0.51 \\
\hline $\mathrm{IOFC},{ }^{3} \$ /$ cow per day & $7.35^{\mathrm{b}}$ & $8.12^{\mathrm{a}}$ & $8.05^{\mathrm{a}}$ & $8.16^{\mathrm{a}}$ & 0.07 & $<0.01$ \\
\hline \multicolumn{7}{|c|}{$\overline{\mathrm{a}-\mathrm{c}}$ Least squares means within the same row without a common superscript differ $(P<0.05)$. } \\
\hline \multicolumn{7}{|c|}{$\begin{array}{l}{ }^{1} \mathrm{CON}=\text { control; } \mathrm{RWR}=15 \% \text { wild rye, } 5 \% \text { corn grain }(\mathrm{CG}) \text {, and } 6 \% \text { soybean meal were replaced by } 15 \% \mathrm{CaO} \\
\text { treated corn stover (T-CS) and } 12 \% \text { dried distillers grains with solubles (DDGS); RCS }=12.5 \% \text { corn silage, } 6 \text { \% } \\
\text { CG, and } 5 \% \text { soybean meal were replaced by } 12.5 \% \text { T-CS and } 12 \% \text { DDGS; RCG }=13 \% \text { CG and } 6 \% \text { soybea } \\
\text { meal were replaced by } 7 \% \text { T-CS and } 13 \% \text { DDGS. }\end{array}$} \\
\hline
\end{tabular}


no significant differences in DMI were observed among the treatments. This inconformity could be interpreted by differences in the source and digestibility of the NDF. In the previous study conducted by Arelovich et al. (2008), all the NDF was not contributed by the by-product feeds, and dietary NDF content varied as a result of changes in proportions of concentrate and forages. In the present study, DDGS was used in the RWR, RCS, and RCG diets $(12,12$, and $13 \%$ of the diet, respectively), which contained high level of readily digestible NDF (more than two-thirds is digestible; Schingoethe et al., 2009). Furthermore, the improved in situ degradability of NDF of T-CS in the current study might also benefit the DMI of dairy cattle, because increased NDF digestibility in vitro or in situ is associated with improved DMI and milk yield of dairy cows (Oba and Allen, 1999).

\section{Milk Production}

The increase in milk yield for RCS treatment was consistent with increased DMI. However, because of the decrease in milk fat percentage, the $4 \% \mathrm{FCM}$ yield for the RWR treatment was similar with the other treatments. The lower content of TS for the RWR, RCS, and RCG treatments was primarily the result of the decreased milk fat and protein percentages. The MUN is formed from $\mathrm{NH}_{3}$ from the rumen and could be used as an indicator of BUN (Nousiainen et al., 2004). Moreover, MUN concentration has often been used to predict the efficiency of $\mathrm{N}$ utilization and is associated with fertility in lactating dairy cows (Rhoads et al., 2004). A negative association existed between MUN concentration and the efficiency of $\mathrm{N}$ utilization for milk protein synthesis (Nousiainen et al., 2004). In the present study, the concentration of MUN was decreased for cows fed the RWR, RCS, and RCG diets, suggesting improved efficiency of $\mathrm{N}$ utilization by these groups.

As an important energy source in the dairy cow diet, starch accounts for 50 to $100 \%$ of nonstructure carbohydrates in most feedstuffs (NRC, 2001). Increasing nonstructure carbohydrate (particularly corn starch) intake might result in an increased nitrogen utilization efficiency and milk yield (Rius et al., 2010). The effect of corn stover diet and alfalfa diet on rumen protein synthesis and performance of dairy cows has been investigated by Zhu et al. (2013). They observed that ruminal energy fermentation was insufficient (lower easily fermentable carbohydrates content) for microbial protein synthesis in the rumen of cows fed the corn-stover diet, leading to decreased milk and protein yields. In the current study, when CG or CS were partially replaced by T-CS and DDGS, different starch content (28.7 vs. 25.5, 22.2, and $20.4 \%$ ) and NFC content (40.1 vs. 37.1,
33.5 , and $32.5 \%$ ) were observed, because DDGS and T-CS had lower starch content than CG and CS. On the other hand, the milk yield, 4\% FCM yield, milk fat yield, milk protein yield, milk lactose yield, and $4 \%$ FCM production efficiency did not decrease in cows fed diets that included T-CS and DDGS. This could be attributed to the nutritional characteristics of DDGS and the effect of chemical treatment on the fermentable carbohydrates content of corn stover. On the one hand, DDGS have been used as a good energy source (high concentration of digestible NDF and fat) and a good protein source (high CP content and ruminally undegradable protein content), which often replace highstarch feeds in dairy cattle diets (Schingoethe et al., 2009). Research by Ranathunga et al. (2010) suggested that nonforage fiber from DDGS can partially substitute for starch from CG in dairy cattle diets without affecting milk yield and milk composition. Moreover, the rumen-fermentable carbohydrates in corn stover may be increased by chemical treatment. In a previous study (Jami et al., 2014), when corn stover was treated by $5 \% \mathrm{NaOH}$, a portion of the cell wall components were solubilized, resulting in an increased content of soluble carbohydrates in the treated corn stover, and a notable decrease in cellulolytic bacteria and an increase in lactic acid-utilizing bacteria were observed in the treated stover group. They inferred that the $\mathrm{NaOH}$ treatment alters the cell-wall structure of corn stover, which may result in an advantage or disadvantage for the different species, and the mechanism by which the effect of T-CS is carried out in modifying the bacterial population in the rumen deserves further research. Similarly, in the current study, a portion of the cell wall components were also solubilized by $\mathrm{CaO}$ treatment; the hemicelluloses content (OM basis) decreased from 30.5 to $22.9 \%$.

\section{Nutrient Digestibility}

Generally, it was expected that replacing CS or CG with low-quality crop residues like corn stover may decrease the nutrient digestibility of dairy cow diets. In the present study, no decrease was observed in nutrient digestibility for the RWR, RCS, and RCG diets compared with the CON treatment. The improved ADF digestibility for the replacement diets might be in part as a result of the increased digestibility of T-CS and highly digestible fiber in DDGS.

The effectiveness of alkali treatment on improving the digestibility of crop residues has been reported by many researchers. As is concluded by Klopfenstein (1978), modes of action of chemical treatment are primarily related to solubilization of hemicelluloses and increase in the extent of digestion of hemicelluloses and 
cellulose. After alkali treatment, rumen microbes were able to attack the structural carbohydrates more easily; hence, higher degradability and intake could be obtained (Wanapat and Cherdthong, 2009).Treating corn stover with $5 \% \mathrm{CaO}$ at $50 \%$ moisture could improve in vitro DM digestibility by $22.13 \%$ (Shreck, 2013). When cows were fed with alkali-treated straw $(2.2 \%$ calcium hydroxide $+2.2 \%$ urea), the DM, OM, CP, $\mathrm{NDF}$, and ADF digestibilities of the diet significantly increased (Wanapat et al., 2009). Effects of T-CS with by-product inclusion have also been studied previously. Sewell et al. (2009) combined T-CS (processing similar to the method described above with $5 \% \mathrm{CaO}$, DM basis) with DDGS to create a CG replacement pellet for lambs. They found that the DM, NDF, and ADF digestibility were improved for T-CS compared with the native form. However, when cracked CG was replaced with corn replacement pellet at $30 \%$ of diet $\mathrm{DM}$, the digestibility of DM and ADF was decreased. In the present study, the DM digestibility was higher for the RWR treatment than the other treatments, and no difference was observed between the RCS, RCG, and CON treatments. Differences between the results in the present study and those of Sewell et al. (2009) could be related to differences in animals used, diet composition, and the type and amount of feed replaced.

\section{Blood Analysis}

Blood cholesterol concentration could be used as an indicator of total lipoprotein concentrations, and it can be affected by dietary fat content (O'Kelly, 1987). Diets that are high in fat can result in increased concentration of blood cholesterol in cows, which is correlated with dietary fatty acid intake (O'Kelly and Robinson, 1968; Talavera et al., 1985; O'Kelly, 1987). In the present study, cows on the CON diet consumed less fat $(480 \mathrm{~g} / \mathrm{d})$ than cows on other diets $(600,619$, and 633 $\mathrm{g} / \mathrm{d}$ for the RWR, RCS, and RCG treatments, respectively). However, the TC concentration was similar for the CON and RWR treatments (4.77 vs. $4.74 \mathrm{mmol} / \mathrm{L}$ ). As a major end product of $\mathrm{N}$ metabolism in ruminants, BUN (NRC, 2001) arises largely from excess RDP, and high concentrations of it usually reflect an inefficient utilization of dietary N (Nousiainen et al., 2004). In addition, high concentrations of BUN may change uterine $\mathrm{pH}$ for several days after estrus and decrease fertility in lactating dairy cows (Rhoads et al., 2004). Cows in the RWR treatment had lower BUN concentrations compared with other treatments, and this was consistent with the lower MUN concentrations for the RWR treatment. Hoover and Miller (1990) summarized reports from several researchers revealing a decrease in BUN concentration in lactating dairy cows when a higher level of ruminally fermentable carbohydrate was supplied to enhance the capture of RDP into microbial protein. In the present study, the lower BUN and MUN concentrations for the RWR treatment might also result from greater carbohydrate degradation in the rumen (T-CS had better in situ effective NDF degradability than WR, and the RWR group had greater ADF digestibility than the CON group), which allowed the microbes in the rumen to use the RDP more efficiently.

\section{Economic Analysis}

Milk and feed prices always are volatile and have a great effect on profits of a dairy farm. Profitability of dairy farms can be measured in many ways. Income over feed cost is an alternative measure of milk and feed prices to the milk-feed ratio of the USDA, and it is more likely to provide fair indication of profitability in periods of volatility (Wolf, 2010).

Results from this research showed that partially replacing WR, CS, or CG with T-CS and DDGS could improve IOFC. Milk prices were slightly decreased on the 3 replacement treatments because of their relatively lower milk fat or milk protein percentages, indicating that higher IOFC could be achieved if milk components of cows fed the replacement diets were regained by some economic and reasonable nutritional regulations. Compared with other feedstuffs, T-CS was cheaper (\$126/t, DM basis). In fact, the corn stover used in this experiment was more expensive than its normal price because of the handling costs because it was collected manually and transported over long distance. The costs would be lower if the corn stover was collected near the farms by mechanized means such as a forage harvester (Xu et al., 2014).

The prices of soybean meal and DDGS are also important factors affecting the IOFC. It is noticeable that the DDGS used in this experiment (imported for the United States) had a higher price than CG (\$440/ ton vs. $\$ 423 / \mathrm{t}$, DM basis). Imported DDGS are usually more expensive than CG in China. It is well known that the price of imported DDGS and soybean meal can be influenced by many factors, such as market demand, domestic DDGS production, and so on. According to the survey data from Chinese Dairy Industry and Technology System, in September 2014, the imported DDGS was cheaper than CG in China ( $\$ 395 / \mathrm{t}$ vs. $\$ 434 / \mathrm{t}$, asfed basis). Increased IOFC can be expected on the 3 replacement treatments when DDGS and soybean meal are cheaper.

\section{CONCLUSIONS}

With continuing rise of feed cost, it is important that continued research be conducted to study the feasibility 
of feeding T-CS and DDGS to ruminants to improve the profitability on dairy farms. Results from this study indicate that partially replacing $\mathrm{WR}$, CS, and $\mathrm{CG}$ in mid- to late-lactation diets with T-CS and DDGS can improve IOFC without negatively affecting the DMI, milk yield, nutrient digestibility, blood metabolites, and BCS of dairy cows. In other words, T-CS combined with DDGS can be a suitable alternative feed for midto late-lactation cows.

\section{ACKNOWLEDGMENTS}

This research was supported by Archer Daniels Midland Company (Decatur, IL) and the National Basic Research Program of the China Ministry of Science and Technology (Beijing, China; No. 2011CB100801). The authors thank the Henan Siyuan Dairy Farm for providing the trial site and animals. Special thanks go to Yuan He and Qi Zhou from China Agricultural University (Beijing, China) for their assistance in feeding of the animals and sampling.

\section{REFERENCES}

AOAC (Association of Official Analytical Chemists). 1990. Official Methods of Analysis. 15th ed. Assoc. Off. Anal. Chem., Arlington, VA.

Arelovich, H. M., C. S. Abney, J. A. Vizcarra, and M. L. Galyean 2008. Effects of dietary neutral detergent fiber on intakes of dry matter and net energy by dairy and beef cattle: Analysis of published data. Prof. Anim. Sci. 24:375-383.

Bal, M. A., J. G. Coors, and R. D. Shaver. 1997. Impact of the maturity of corn for use as silage in the diets of dairy cows on intake, digestion, and milk production. J. Dairy Sci. 80:2497-2503.

Cao, Z. J., H. T. Shi, D. F. Li, and S. L. Li. 2015. Progress on nutritional evaluation of ruminant feedstuff in China. Acta Prataculturae Sinica 24:1-19.

Chapple, W. P. 2014. Effects of replacing corn in beef feedlot diets with chemically or thermochemically treated corn stover and distillers grains on growth performance, carcass characteristics, and ruminal metabolism. MS Thesis. Univ. Illinois Urbana-Champaign, Urbana.

Cheng, X. P. 2013. Influence factors of dairy cow breeding profit in China: An empirical study based on provincial panel data. J. Chongqing Univ. Tech. Soc. Sci. 27:41-44.

Dong, X. X., Z. M. Li, S. W. Xu, and G. Q. Li. 2013. Study on price transmission mechanism between corn, beanpulp and milk in China based on MCM approach. J. Syst. Sci. Math. Sci. 33:55-66.

Edmonson, A. J., I. J. Lean, L. D. Weaver, T. Farver, and G. Webster. 1989. A body condition scoring chart for Holstein dairy cows. J. Dairy Sci. 72:68-78.

FASS. 2010. Guide for the Care and Use of Agricultural Animals in Research and Teaching. 3rd ed. Fed. Anim. Sci. Soc., Champaign, IL.

Forbes, J. M., and F. D. Provenza. 2000. Integration of learning and metabolic signals into a theory of dietary choice and food intake. Pages 3-19 in Ruminant Physiology: Digestion, Metabolism, Growth and Reproduction. P. Cronje, ed. CAB Int., Wallingford, UK.

Gandi, J., M. T. Holtzapple, A. Ferrer, F. M. Byers, N. D. Turner, M. Nagwani, and S. Chang. 1997. Lime treatment of agricultural residues to improve rumen digestibility. Anim. Feed Sci. Technol. $68: 195-211$.
Hoover, W. H., and T. K. Miller. 1990. Carbohydrate and protein considerations in ration formulation. Page 71 in Proc. Large Dairy Herd Manage. Conf. Cornell Coop. Ext., Cornell Univ., Ithaca, NY.

Jackson, M. G. 1977. Review article: The alkali treatment of straws Anim. Feed Sci. Technol. 2:105-130.

Jami, E., N. Shterzer, E. Yosef, M. Nikbachat, J. Miron, and I. Mizrahi. 2014. Effects of including $\mathrm{NaOH}$-treated corn straw as a substitute for wheat hay in the ration of lactating cows on performance, digestibility, and rumen microbial profile. J. Dairy Sci. 97:1623-1633.

Klopfenstein, T. J. 1978. Chemical treatment of crop residues. J. Anim. Sci. 46:841-848.

Lv, K. Y., H. G. Qiu, J. F. Bai, and Z. G. Xu. 2013. Development of direct return of corn stalk to soil: Current status, driving forces and constraints. China Pop. Resour. Environ. 23:171-176. (In Chinese).

Miron, J., and D. Ben-Ghedalia. 1987a. Nutritional implication associated with increasing the fermentability of straw by chemical and enzymatic treatments. J. Dairy Sci. 70:1864-1875.

Miron, J., and D. Ben-Ghedalia. 1987b. Digestibility by sheep of total and cell-wall monosaccharides of wheat straw treated chemically or chemically plus enzymatically. J. Dairy Sci. 70:1876-1884.

Nousiainen, J., K. J. Shingfield, and P. Huhtanen. 2004. Evaluation of milk urea nitrogen as a diagnostic of protein feeding. J. Dairy Sci. $87: 386-398$.

NRC. 2001. Nutrient Requirements of Dairy Cattle. 7th ed. Natl Acad. Sci., Washington, DC.

O'Kelly, J. C. 1987. Influence of dietary fat on some metabolic responses of cattle to hyperthermia induced by heat exposure. Comp. Biochem. Physiol. A Comp. Physiol. 87:677-682.

O'Kelly, J. C., and D. W. Robinson. 1968. The effect of drought feeding with whole cottonseed, and vitamin therapy, on the serum lipids and liveweight changes of beef cattle in North-western Australia. Crop Pasture Sci. 19:657-664.

Oba, M., and M. S. Allen. 1999. Evaluation of the importance of the digestibility of neutral detergent fiber from forage: Effects on dry matter intake and milk yield of dairy cows. J. Dairy Sci. $82: 589-596$

Ørskov, E. R., F. D. D. Hovell, and F. L. Mould. 1980. The use of the nylon bag technique for the evaluation of feedstuffs. Trop. Anim. Pro. 5:195-213.

Ranathunga, S. D., K. F. Kalscheur, A. R. Hippen, and D. J. Schingoethe. 2010. Replacement of starch from corn with nonforage fiber from distillers grains and soyhulls in diets of lactating dairy cows. J. Dairy Sci. 93:1086-1097.

Rhoads, M. L., R. O. Gilbert, M. C. Lucy, and W. R. Butler. 2004. Effects of urea infusion on the uterine luminal environment of dairy cows. J. Dairy Sci. 87:2896-2901.

Rius, A. G., J. A. D. R. N. Appuhamy, J. Cyriac, D. Kirovski, O. Becvar, J. Escobar, M. L. McGilliard, B. J. Bequette, R. M. Akers, and M. D. Hanigan. 2010. Regulation of protein synthesis in mammary glands of lactating dairy cows by starch and amino acids. J. Dairy Sci. 93:3114-3127.

Schingoethe, D. J., K. F. Kalscheur, A. R. Hippen, and A. D. Garcia. 2009. Invited review: The use of distillers products in dairy cattle diets. J. Dairy Sci. 92:5802-5813.

Sewell, J. R., L. L. Berger, T. G. Nash, M. J. Cecava, P. H. Doane, J. L. Dunn, M. K. Dyer, and N. A. Pyatt. 2009. Nutrient digestion and performance by lambs and steers fed thermochemically treated crop residues. J. Anim. Sci. 87:1024-1033.

Shreck, A. L. 2013. Use of alkaline treated crop residues as partial grain replacements for finishing cattle. Doctoral Thesis. Univ. Nebraska, Lincoln

Shreck, A. L., C. D. Buckner, G. Erickson, T. Klopfenstein, and M. J. Cecava. 2011. Digestibility of crop residues after chemical treatment and anaerobic storage. Nebraska Beef Cattle Rep. 94:35-36.

Sirohi, S. K., and S. N. Rai. 1998. Optimisation of treatment conditions of wheat straw with lime: Effect of concentration, moisture content and treatment time on chemical composition and in vitro digestibility. Anim. Feed Sci. Technol. 74:57-62. 
Talavera, F., C. S. Park, and G. L. Williams. 1985. Relationships among dietary lipid intake, serum cholesterol and ovarian function in Holstein heifers. J. Anim. Sci. 60:1045-1051.

Tyrrell, H. F., and J. T. Reid. 1965. Prediction of the energy value of cow's milk. J. Dairy Sci. 48:1215-1223.

USDA-ERS. 2010. Monthly cost of production estimates. USDA-Econ. Res. Serv., Washington, DC. Accessed May 6, 2010. http://www. ers.usda.gov/data-products/milk-cost-of-production-estimates. aspx.

Van Soest, P. J. 1994. Nutritional Ecology of the Ruminant. 2nd ed. Comstock Publ. Assoc., Cornell Univ. Press, Ithaca, NY.

Van Soest, P. J., J. B. Robertson, and B. A. Lewis. 1991. Methods for dietary fiber, neutral detergent fiber, and nonstarch polysaccharides in relation to animal nutrition. J. Dairy Sci. 74:3583-3597.

Wan, C. X., and Y. B. Li. 2010. Microbial delignification of corn stover by Ceriporiopsis subvermispora for improving cellulose digestibility. Enzyme Microb. Technol. 47:31-36.

Wanapat, M., and A. Cherdthong. 2009. Use of real-time PCR technique in studying rumen cellulolytic bacteria population as af- fected by level of roughage in swamp buffalo. Curr. Microbiol. 58:294-299.

Wanapat, M., S. Polyorach, K. Boonnop, C. Mapato, and A. Cherdthong. 2009. Effects of treating rice straw with urea or urea and calcium hydroxide upon intake, digestibility, rumen fermentation and milk yield of dairy cows. Livest. Sci. 125:238-243.

Wolf, C. A. 2010. Understanding the milk-to-feed price ratio as a proxy for dairy farm profitability. J. Dairy Sci. 93:4942-4948.

Xu, Y. Y., Y. S. Tian, L. X. Zhao, Z. L. Yao, S. L. Hou, and H. B. Meng. 2014. Comparison on cost and energy consumption with different straw's collection-store-transportation modes. Trans. Chinese Soc. Agric. Eng. 30:259-267.

Zaman, M. S., and E. Owen. 1995. The effect of calcium hydroxide and urea treatment of barley straw on chemical composition and digestibility in vitro. Anim. Feed Sci. Technol. 51:165-171.

Zhu, W., Y. Fu, B. Wang, C. Wang, J. A. Ye, Y. M. Wu, and J. Liu. 2013. Effects of dietary forage sources on rumen microbial protein synthesis and milk performance in early lactating dairy cows. J. Dairy Sci. 96:1727-1734. 